undiagnosed by cystoscopy and routine radiology. When symptoms are recurrent or there is proteinuria between attacks of haematuria a positive histological diagnosis is more likely and has the advantage of making repetitive radiology or even surgery less likely.

J Michael

$\mathrm{N}$ F JONES

D R DAVIES

J R TIGHE

\section{St Thomas's Hospital and}

London SE1

${ }^{1}$ Michael, J, et al, British Medical fournal, 1976, 1, 686

\section{Distalgesic}

SIR,-An examination of the latest available mortality statistics ${ }^{1}$ shows that since 1964 the decreasing availability of the traditional methods of self-poisoning-for example, coal gas-has coincided with an increase in the abuse of other agents such as psychotropics and analgesics (aspirin, paracetamol, etc), the majority of the latter being obtained from retail sources.

The recent article by $\mathrm{Dr} \mathrm{R} M$ Whittington (16 July, p 172) confirms previous reports ${ }^{2}$ that Distalgesic (paracetamol + dextropropoxyphene) is the most widely prescribed analgesic in the United Kingdom and it is perhaps not surprising that, unfortunately, a small minority should seek to abuse it. However, statistics indicate that annually many more deaths result from ingestion of aspirin and paracetamol.

The problem associated with the taking of quantities of alcohol with centrally acting drugs is well known to physicians and we stress this in our literature. ${ }^{4}$ However, the effectiveness and safety of Distalgesic are confirmed by its 13 years of widespread clinical use, which has shown that it does not present a problem when taken as directed.

C J WICKs Medical Director Lilly Industries Ltd

Basingstoke, Hants

${ }^{1}$ Office of Population Censuses and Surveys, Mortality
Statistics 1974, series DH1, No 1. London, HMSO, Statistics 1974, series DH1, No 1. London, HMSO, Skegg, D C G, Doll, R,

Fournal, 1977, 1, 1561. Statistics 1974, series DH4, No 1. London, Mortality Statis
1976.

' ABPI Data Sheet Compendium, 1977.

\section{Perforating diverticulitis}

SIR,-I am prompted to write by a statement in your recent leading article headed "Perforating diverticulitis" (2 July, p 5). While agreeing that a conservative policy of management is often rewarding in inflammatory diverticular disease and welcoming the reemergence of the old-fashioned expression "a phlegmon," I cannot accept that the use of intravenous fluids and broad-spectrum antibiotics should be advocated for an appendix abscess.

The management of two patients recently may illustrate the point. The first, a 42-year-old man had a $3 \frac{1}{2}$-year history of a sinus in the right loin. A suspected perinephric abscess had originally been opened, but the drainage site had intermittently discharged. He presented several times with right iliac fossa pain and the discharging sinus, each time managed conservatively with antibiotics. Eventual laparotomy revealed an abscess cavity around the appendix which had a chronic perforation at its centre, through which threadworms moved freely.

The second case involved a suspected carcinoma of the caecum in a 74-year-old woman. Her story of right iliac fossa pain and a febrile illness of three months before was not forthcoming until after a laparotomy had revealed an abscess cavity in the right iliac fossa. This had formed around a small bone from the flying fox (a species of bat which is a culinary delicacy here), which had perforated the caecum.

I feel that neither of these patients would have been greatly served by a regimen of intravenous fluids and antibiotics and, although not absolutely typical of the case which you presumably had in mind, serve to emphasise that adequate surgical drainage remains the basis of successful treatment of an abscess.

JoHN C Nicholls

Victoria Hospital

SIR,-I was interested to read Mr D D Rao's report (16 July, $p$ 192) of a solitary perforated diverticulum of the ascending colon. This is a rare condition which the average surgeon meets on only one or two occasions during his "emergency surgery period." I had the doubtful privilege of extending this period beyond all reasonable lengths and was able, in 1962, to report $^{1}$ a personal series of six such cases encountered during a 10-year senior registrar stint. The condition can occur at any age-my patients' ages ranging from 12-62-and is always misdiagnosed as acute appendicitis. On opening the abdomen a further misdiagnosis is nearly always made and a right hemicolectomy performed on the assumption that one is dealing with carcinoma. This is because the ruptured diverticulum is surrounded with a firm inflammatory exudate. I made this mistake in my first case, but in the remaining five was forewarned and was able to resect out the offending diverticulum and remove it.

\section{Ashford Hospital,}

ROBIN BURKITT

'Burkitt, R T, Postgraduate Medical fournal, 1962, 38,
442.

\section{Percutaneous peritoneal biopsy}

SIR,-We were interested to read your leading article (18 June, p 1557) concerning abdominal tuberculosis in Britain as we recently diagnosed tuberculous peritonitis in a woman presenting with ascites by the technique of percutaneous peritoneal biopsy. The ascitic fluid contained $43 \mathrm{~g}$ protein/l and moderate numbers of leucocytes, but examinations for mycobacteria on direct smear were repeatedly negative. Percutaneous peritoneal biopsy was performed with an Abram's needle through a small skin incision in the right iliac fossa. Histological examination revealed caseating granulomata and large numbers of acid alcohol-fast bacilli.

It is instructive to compare the findings in this patient with those in patients with tuberculous pleural effusion, in whom pleural biopsy is positive in approximately $80 \%$ of cases, although mycobacteria are rarely seen on direct smear on pleural fluid. As far as we are aware, peritoneal biopsy is not commonly practised in Britain, although it is used more extensively in the United States, ${ }^{1}$ where the diagnostic yield in tuberculous peritonitis (with the blunt-ended Cope needle) is as high as $60-90 \%{ }^{2}$

In the presence of ascites percutaneous peritoneal biopsy is a safe and relatively simple bedside technique; its diagnostic yield is high and we suggest that it may be used to advantage in the investigation of ascites and particularly when tuberculous peritonitis is suspected.

P JENKINS RICHARD BURDEN C R Elston

City Hospital,
Nottingham

1 Viranuvatti, V, et al, American fournal of Proctology, $1966,17,488$.

2 Levine, H, Archives of Internal Medicine, 1967, 120,

\section{Disulfiram blood levels}

SIR,-Drs L Ranek and P B Andreasen (9 July, p 94) claim that "the pharmacokinetics of disulfiram have not been elucidated because there are no sensitive and specific methods of determining disulfiram and its metabolites."

Disulfiram is a very difficult drug to understand, but we have described a method of measuring blood levels clinically. ${ }^{12}$ After oral disulfiram therapy levels of $2-8 \mathrm{mg} / 1$ were obtained, and immediately after implantation levels of $1-3 \mathrm{mg} / 1$ were recorded. ${ }^{3} \mathrm{~A}$ final metabolite of disulfiram is carbon disulphide. This gas was measured in the breath of disulfiram-treated patients and levels of $0 \cdot 1-0 \cdot 4 \mathrm{mg} / \mathrm{m}^{3}$ were obtained. ${ }^{3}$

M T MaLcolm

West Cheshire Hospital,

Chester

${ }^{1}$ Porter, G S, and Williams, A E, fournal of Pharmacy and Pharmacology, 1972, 24, suppl, p 144. 2 Brown, M, Porter, G S, and Williams, A E, fournal of Pharmacy and Pharmacology, 1974, 26, suppl, p 95. Malcolm, M T, Madden, J S, and Williams. A E, British fournal of Psychiatry, 1974, 125, 485.

\section{Trace elements in intravenous feeding} of infants

SIR,-Your leading article "Intravenous feeding in infancy" (11 June, p 1490) quotes Fox and Krasma, ${ }^{1}$ supporting the recommendation to supply the need for trace elements by giving " $10 \mathrm{ml} / \mathrm{kg}$ fresh frozen plasma every week." Fox and Krasma, like many other authors, simply state that they rely on this procedure but do not provide any data to support its adequacy. A simple calculation based on normal plasma levels and on recommended allowances for zinc, for example, easily shows that such a procedure will scarcely change anything and will certainly not supply any substantial amounts of zinc. "Normal" adult human plasma (the source of "fresh frozen

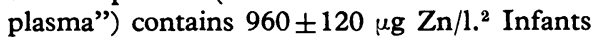
on parenteral nutrition require $40 \mu \mathrm{g} \mathrm{Zn/kg}$ day $^{3}$ or $280 \mu \mathrm{g} \mathrm{Zn} / \mathrm{kg} /$ week. Thus fresh frozen plasma in a dose of $10 \mathrm{ml} / \mathrm{kg} /$ week will supply at the best $10.8 \mu \mathrm{g} / \mathrm{kg} /$ week-that is, only about $1 / 30$ th of the required amount.

Infants on parenteral nutrition are sick babies, not normally thriving ones. Catabolism, wound healing, and catch-up growth enormously increase the demand for zinc. It is therefore obvious that $10 \mathrm{ml}$ plasma/ $\mathrm{kg} /$ week will in no case, not even in healthy ones, supply 